\title{
Optimal Regional Trade-Integration Schemes in North Africa : Toward a Pro-Industrialization Policy
}

\author{
Simon Mevel \\ United Nations Economic Commission for Africa, Addis Ababa, Ethiopia \\ Jaime Moll de Alba \\ United Nations Industrial Development Organization, Vienna, Austria
}

Nassim Oulmane

United Nations Economic Commission for Africa, Addis Ababa, Ethiopia

\begin{abstract}
This article examines the status of industrial production in North African Countries as well as the role that regional trade integration through free-trade agreements and trade facilitation may play in spurring this region's reindustrialization. The study uses Applied General Equilibrium model to assess the potential impact of the establishment of a Continental Free Trade Area as well as the reduction of costs to trade across borders. This article also measures the additional impact of the implementation of the Great

\footnotetext{
* Corresponding Author: Nassim Oulmane; United Nations Economic Commission for Africa, P.O. Box 3001, Addis Ababa, Ethiopia; Tel: +251 115443089, E-mail: oulmane@uneca.org.

Co-authors: Simon Mevel; United Nations Economic Commission for Africa, P.O. Box 3001, Addis Ababa, Ethiopia; Tel: +251115443695, E-mail smevel@uneca.org.

Jaime Moll de Alba; United Nations Industrial Development Organization, P.O. Box 300, 1400 Vienna, Austria; Tel: +43 1260263291, E-mail: J.Moll-de-Alba@unido.org.

Acknowledgements: The article is a revised version of UNIDO Working Paper 01/2015 written by the authors. The authors would like to thank Dr Mustapha Sadni-Jallab for his extensive comments and the participants of the 18th Annual Conference on Global Economic Analysis "Information for the Policy Maker: Practical Economic Modelling for Tomorrow" in Melbourne in June 2015 for their comments. The responsibility for the opinions expressed in this article rests solely with the authors and they do not necessarily reflect the views of UNECA and UNIDO.
} 
Arab Free Trade Area and, finally, a deeper free trade agreement among North African countries and the European Union. The main findings indicate that each free-trade agreement configuration will stimulate, in relative terms, North African countries' exports from a number of main industries. Whereas industrial products represent the largest share of North African countries' export gains to Africa in general, mining and energy dominate North African countries' export gains to the rest of the Arab League and food dominates the exports to the European Union. Therefore, the establishment of the Continental Free Trade Area, accompanied by trade-facilitation measures, appears to be crucial in providing support for North African countries' industrialization.

JEL Classifications: F14, F15, F63, O14, O19

Keywords: Regional Trade Agreements, Industrialization, Trade Facilitation

\section{Introduction}

The economic emergence of North African Countries ${ }^{1}$ (NACs) requires a significant transformation of their economies and raises the question about their structural change. Despite their different levels of diversification, the economic performance of most countries in the North Africa region remains dependent on either commodity prices or weather conditions. North African economies are, in general, poorly diversified and specialized in only a handful of industries or non-dynamic products with low added value (EIB 2015). The high levels of unemployment, particularly among young people, call for the urgent creation of several million jobs in the region. Only a significant increase in economic growth can help meet this pressing challenge. Such an increase, often called explosive growth, has been experienced through structural change in either industries or services in the past. The growing participation in international trade, namely through manufactured exports, which are increasingly diverse and sophisticated, signifies a prominent engine to drive the structural transformation of successful developing countries.

NACs began diversifying their structures in the 1960s and 1970s through state-led

In this paper, NACs refers to Algeria, Egypt, Libya, Morocco, Tunisia, and Sudan. However, in the simulations, Sudan is not included with the rest of North Africa. 
import-substitution strategies (Morocco, Tunisia) or heavy industrialization strategies (Algeria, Egypt). The diversification of their economies continued at different rates during the period of structural change in the 1980s and 1990s. As a result, the economic structures of most countries in the region changed between the mid-1980s and 2007, as demonstrated by the larger shares of industry and services in their economies. This change was also confirmed by the increase in diversification indices (Ben Hammouda et al. 2009), particularly in Egypt, Tunisia, and, to a lesser extent, Morocco. These countries' share in the global market of manufactured goods has, however, remained marginal at slightly above 1\% between 1975 and 2008, while East Asia's share increased from 1.7 to $20 \%$ in the same period.

The apparent paradox between the level of diversification and international integration of NACs can be explained by several factors - on the one hand, by their relatively slow pace of diversification compared with that of the rest of the world and, on the other, by their focus on not necessarily the most dynamic global products concomitant with limited growth of Manufacturing Value Added (MVA). Moreover, North Africa's regional market has witnessed increasing competition from newcomers such as China, India, and Turkey. All of these factors have resulted in the currently limited integration of these countries into Global Value Chains (GVCs), which account for a significant share of global MVA.

Since 2008, North Africa's MVA growth rate has declined, as in almost all world regions, partly as a consequence of the overall global economic downturn. North Africa lags behind the world's most dynamic regions in terms of MVA per capita. Moreover, the existing gap has widened given the stagnant MVA per capita growth rate experienced in the 2008 2012 period (Moll de Alba 2014). Manufacturing plays a less significant role in North Africa than in other developing regions. It has not expanded during the last decade and its contribution to the region's economy is limited. MVA represents one-tenth of the region's Gross Domestic Product (GDP), and the growth of the manufacturing sector lags behind that of the economy as a whole. The region has partly undergone a process of deindustrialization, whereas significant structural change has failed to take place during the last years.

The experience of developed as well as of emerging countries, particularly in Asia, demonstrates that that they have achieved real development (UNIDO 2009). Similarly, some studies show that the transition from being a low-middle income country takes place through the development of a strong and diversified economy, with the state playing a role in this process (Imbs and Wacziarg 2003). Recent research (UNIDO 2016) 
shows that manufacturing will still offer ample opportunities for developing countries to grow in the coming years. Haraguchi et al. (2016) confirm that manufacturing continues to offer prospects for developing countries, and they conclude that a small number of developing countries comprise a significant part of the MVA of this country grouping, whereas a large group of developing countries have failed to develop their manufacturing sector. For economies such as that of NACs, in which minerals and hydrocarbons are abundant, structural change should take place through the acceleration of the pace of diversification toward manufactured goods and through the introduction of more dynamic and efficient technologies. Indeed, the literature suggests that beyond economic diversification and exports, the nature of this particular diversification and sophistication in the process of production and exports serves as the lever for these economies to undertake structural shifts (Hausmann et al. 2007).

Active policy reforms have proven to play an important role in supporting this process. Trade policy can make significant contributions, particularly to increases in processing, thereby leading to higher value added. Regional trade agreements may constitute a key instrument to raise NACs' participation in global trade. The positive growth prospects of the African continent may convert the Continental Free Trade Agreement (CFTA) ${ }^{2}$ into a major ex-ante opportunity for NACs to expand their manufactured exports, given the continent's rapid urbanization and demographic evolution (UNECA 2014). This assumption needs to be assessed to measure the extent to which such trade reforms could play a pivotal role in NACs' reindustrialization. Besides the CFTA, NACs are involved in two other major regional integration processes, namely the Great Arab Free Trade Area (GAFTA) with the countries of the League of Arab States (LAS) and the Euro-Mediterranean Partnership (EUROMED) process with the EU.

Given the relatively modest size of NACs' economies - and in fact of the entire region - a deeper integration with not only the African continent but also the LAS countries and those within the EUROMED framework might strengthen the optimization of the region's comparative advantages. However, this process will not entail the same pattern of trade with each partner, particularly with regard to manufactured exports.

The purpose of this article is to assess different scenarios of regional integration with the main NAC trade partners and to identify the form of regional integration and trade

\footnotetext{
2 At the 2012 African Union (AU) Summit, African heads of state and governments endorsed an AU action plan for boosting intraAfrican trade and establishing the CFTA; it was agreed that the CFTA, for which negotiations were successfully launched at the June 2015 AU Summit, would be tentatively established by 2017.
} 
agreements that would imply a higher level of industrialization of NACs.

This paper is structured as follows. After this general introduction, Section II provides an overview of recent developments in terms both of regional integration and industrial development. Section III presents the methodology and different scenarios for the regional trade integration analysis. Section IV discusses the main findings of the trade reforms envisaged on the basis of NACs' trade and income performance. Finally, Section V provides a set of trade policy recommendations.

\section{Overview of Recent Trends}

\section{A. Regional integration in North Africa}

North Africa's regional integration process is limited and falls short of the ambitions expressed by the countries through different treaties and agreements; it can also be considered delayed, compared with developments in the rest of the continent. Indeed, if we consider the most evident and simple indicator-intra-regional trade- the performance of the region remains low: intra-regional exports represented only $6 \%$ of total exports in 2014, and intra-regional imports are 5\% of imports. Even the nature of the trade is not in favor of strengthening economic links through regional value chains. The structure of intra-sub regional trade shows a predominance of low value-added goods since the sub-region's trade is mainly fuel (up to 43\%) and other commodities (up to $18 \%$ ).

The growth pattern over time shows an increasing gap in terms of low value-added goods, particularly fuels, the share of which has been increasing in recent years, from less than $30 \%$ of trade in 2010 to more than $43 \%$ in 2013.

The impact of the events experienced by the sub-region since 2011 is particularly obvious for manufactures, the share of which declined by $24 \%$; however, the share of commodities, including fuels, showed positive growth rates in the same period.

Nearly two thirds of intra-North African trade is provided by Algeria (36\%) and Egypt (30\%). Tunisia comes third with 17\%, whereas the share of Sudan and Mauritania is less than $1 \%$.

At the institutional level, the only Regional Economic Community (REC) in North 
Africa is the Arab Maghreb Union (AMU), which was established in 1989 in Marrakech through a treaty signed by Algeria, Libya, Mauritania, Morocco, and Tunisia. Although this REC has an ambitious agenda and aims to organize an economically integrated space in the Maghreb region and set up common policies in all domains, it has, so far, been unsuccessful in implementing a deep regional integration process. The five signatory countries have just finalized the negotiations around the Free Trade Area (FTA), which is expected to start late 2016, despite it being scheduled for 1992 according to the Marrakech treaty.

One of the most common reasons given for these delays is the regular political tensions arising during the last 25 years between some AMU member states. However, in several regional integration processes, existing political tensions between countries were not a hindering factor, compared with the potential economic and social gains related to the deep integration process. In the case of AMU, political tensions become an obstacle for reasons linked to the Treaty establishing the AMU. Indeed, this Treaty stipulates (article 4) that the Union is endowed with a council of Presidency consisted of the members' Heads of States and which is the supreme organ of the Union. Article 6 clarifies that only the Presidential Council is authorized to make decisions and its decisions shall be taken unanimously.

These two articles have serious implications for the regional integration process. Indeed, it means that all decisions to be implemented should be taken by heads of state. Given the political tensions that exist between countries in the region and taking into account the political situation in Libya, which has faced the absence of a strong unified government since the Arab Spring in 2011, it is obvious that the regional integration process in the Maghreb is completely frozen, as the last summit for heads of states was held back in 1994.

Regarding Egypt and Sudan, both these countries are members of the Common Market for Eastern and Southern Africa (COMESA), and since June 2015, they have taken part in the tripartite agreement, signed in Sharm Echeikh, that merged COMESA with the South African Development Community (SADC) and East African Community (EAC), involving 26 African countries. This new dynamic is expected to stimulate a broader agenda that includes all other African countries through continent-wide reform. 


\section{B. Industrial development status}

Africa's manufacturing sector is underdeveloped (Bigsten and Söderbom 2011, Lall 2005, UNIDO 2009, 2013a, 2013b, UNCTAD and UNIDO 2011), as is the North African manufacturing sector, which has had minimal impact on the region's economic growth. The region has missed the opportunities offered by past commodities booms. Moreover, the impact of the global economic and financial crisis of 2008, together with the social and political changes of 2009 and 2011 affecting some countries in the region, have resulted in a significant slowdown of industrial performance.

North Africa experienced a decline in its MVA growth rate, which dropped to $1.67 \%$ in the 2008 2013 period. The region displayed the highest MVA per capita within Africa (276 US dollars) in 2013 but experienced only a marginal increase of $0.20 \%$ during 2008 2013. North Africa increased its MVA per capita marginally by 2 US dollars in the 2008 2013 period, compared with a 108 US dollars increase in developing countries during the same period.

The average annual MVA growth rates declined during 2008 2013 in all countries within the region compared with the previous period. Egypt, with more than $40 \%$ of the region's MVA, saw its growth rate halved to $2.73 \%$, whereas Libya's growth rate dropped to $-12.93 \%$.

As a result, NACs recorded reductions in their MVA per capita average growth rates. Tunisia serves as the exception, having experienced a higher growth rate per capita in the 2008 2013 period than in the 2003 2008 period. Tunisia topped the per capita value in North Africa at 634 US dollars, nearly double that of Morocco. Both Algeria and Libya experienced declines in their MVA per capita during 2008 2013, 181 to 170 US dollars and from 431 to 204 US dollars, respectively.

Nonetheless, North Africa, jointly with Southern Africa, still accounts for the largest share of Africa's MVA. They also display the largest share of Medium- and HighTechnology (MHT) products in the region-23\% in the case of North Africa. Resourcebased activities, however, account for almost half of North Africa's MVA.

Overall, Africa's industrialization level declined to a low 9.88\% share of MVA in GDP in 2013. This trend experienced by the continent over the 1950 2005 period (Szirmai 2012) — with manufacturing following a flat trajectory to reach a share of 11 percent MVA in GDP in 2005, equivalent to that of 1950 - has, unfortunately, not been reversed. Page (2012) confirms that Africa has deindustrialized since the 1970s and that the continent requires structural changes to ensure and sustain future growth. However, 
the challenge to accelerate and sustain the growth of Sub-Saharan Africa persists (Abarche et al. 2008) despite some progress.

North Africa does not constitute, unfortunately, a different case in the continent: that is to say, the percentage of MVA in GDP declined to $10.40 \%$ in 2013. Africa's manufacturing sector grew at a slower pace than its economy during 2008 2013. Africa's recent economic growth has not been accompanied by significant structural change. This trend is confirmed by its declining growth rates during 2008 2013. North Africa displays a similar performance as its MVA grew slower than its GDP.

North Africa's manufacturing is weak and thus contains ample scope to further contribute to boosting and sustaining the region's economic growth. North Africa continues to represent a marginal share of the world's manufacturing added value and manufactured exports (Upadhyaya and Mirzaei Yeganeh 2015). Due to, among other reasons, the political and social changes of 2009 and 2011 and the strong dependence on a handful of markets that have suffered severe downturns since 2008, Egypt, Tunisia, and Morocco, which have the region's largest industrial sectors, have witnessed either a decline or stagnation of the manufacturing sector and its contribution to the countries' economic growth. The region has, unfortunately, not made use of past commodity booms and related economic growth to propel its structural transformation.

\section{Methodology}

\section{A. Main model}

This analysis relies on the Modelling International Relationships in Applied General Equilibrium (MIRAGE) multi-country, multi-sector Computable General Equilibrium (CGE) model, which is particularly well suited for trade policy analysis. The dynamic version of the model is utilized with its standard closure. The dynamic is recursive, implying a succession of equilibria being solved sequentially from one year to another. ${ }^{3}$ The model relies on the Global Trade Analysis Project (GTAP) database version $8.1^{4}$ for

\footnotetext{
${ }^{3}$ See Decreux and Valin (2007) for a full description of the model features.

${ }^{4}$ See Narayanan et al. (2012).
} 
macroeconomic and bilateral trade data, whereas the Market Access Map at Harmonized System 6-digit (MAcMap-HS6) database version 2 is employed for bilateral protection information. The MAcMap-HS6 database is updated with key developments to date (such as the Everything But Arm (EBA) initiative, the African Growth and Opportunity Act (AGOA) and expansion of the EU to 28 members).

Considering both the solver's limitations and GTAP database's constraints in terms of geographic and sectoral details, simulations are conducted with a total of 14 countries or regions and 29 industries. As the focus here is on North Africa, all NACs available in the GTAP version 8.1 database are retained. ${ }^{5}$ The remaining African countries are categorized into 4 other African regions. The main trading partners (i.e., the EU, the United States, and China) are also retained as they are available in the database, whereas all other countries and regions are aggregated into two groups: Emerging Industrialized Economies (EIE), and Rest of the World (see Appendix 1).

Regarding sectoral aggregation, emphasis is placed on manufacturing industries that are incremental for NACs' structural transformation. In other words, as many details as possible were retained for these industries. In total, 29 industries were considered, which can be decomposed into Agriculture (1), Food (7), Industrial Manufacturing (16), Mining and Energy (3), and Service Sectors (2) (see Appendix 2).

\section{B. Description of trade reforms}

Three sets of trade reforms are assumed based on North African countries' ongoing efforts to broaden trade integration with their African, Arab and Euro Mediterranean partners. Each set of reforms builds on each other in the sense that the first set of scenarios envisages only North Africa's engagement with its African partners. The second set of scenarios, more ambitious, considers not only pan-African integration but also pan-Arab integration. The third set of scenarios assumes that North African economies have been able to successfully integrate with their trading partners from the African, Arab and Euro Mediterranean regions. The objective being to assess whether the level of industrialization of NACs vary significantly with the envisaged integration reforms. Greater details on each of the three sets of trade reforms are provided thereafter.

\footnotetext{
${ }^{5}$ It should be noted that Algeria and Libya are lumped together into the GTAP database under the Rest of North Africa region; therefore, results from the simulation exercise cannot be drawn for these two countries separately. Similarly, Sudan is part of the Rest of Eastern Africa region in the GTAP database.
} 
Firstly, a clear roadmap for Africa's regional integration process was initially provided by the Abuja Treaty, which came into effect in 1994. In accordance with the Treaty ${ }^{6}$, African heads of state and government agreed in January 2012-by endorsing the African Union Action Plan for Boosting Intra-African Trade and the Establishment of a Continental Free Trade Area - to set up a CFTA, with 2017 as the tentative target. CFTA negotiations have officially been launched at the June 2015 African Union Summit in South Africa, with objective date to launch the CFTA unchanged. Accordingly, the first scenario devised in this analysis assumes that all tariff barriers on goods within the African continent will be removed by 2017. An alternative scenario is to consider a reduction of costs to trade across borders in addition to the trade liberalization associated with the CFTA, assuming that all countries implement the trade facilitation part of the WTO agreement reached in December 2013, referred to as the Bali package. These trade costs are obtained by crossing information on (1) the average number of days required for export and import processes (World Bank 2013) and (2) export- and importweighted average time costs obtained at the GTAP level of industries. The trade costs were also obtained by exporting and importing countries/regions (Minor and Hummels 2011). $25 \%$ reductions of these trade costs, or iceberg costs, were then applied, such as customs procedures, port handling, and inland transport in import and export processes, which are assumed to become more efficient worldwide by 2017 compared with the base year. The assumption is that reforms will lead to improved productivity (PortugalPerez and Wilson 2010) and, in particular, improve the competitiveness of manufactured industrial products. Trade facilitation can boost productivity; Karingi and Spence (2011) confirm these results on TFP from a sample of 18 African countries and indicate that trade facilitation can also influence production, catalyzing a transition toward more sophisticated exports and greater future growth.

The second set of scenarios is based on the first, with an additional FTA within the GAFTA framework. The implementation of the Pan-Arab FTA has already started in most Arab countries. However, in many cases, product coverage is low and exclusion lists of sensitive products are important. In this scenario, we assume a full FTA by 2017 , without any exceptions. As for the first scenario, we assess an alternative reform that includes a $25 \%$ reduction in the costs of trade across borders by 2017.

The third set of scenarios is based on the second set, to which we add a comprehensive

\footnotetext{
${ }^{6}$ It should be noted that if the CFTA was not specifically mentioned in the Abuja Treaty it was implicitly required by the indication of the need for Africa to come up with its Continental Customs Union (i.e. a CFTA with a single common external tariff structure for all African countries vis-à-vis partners from outside Africa) by 2019.
} 
FTA between NACs and EU countries. This scenario is an expansion of the current bilateral EUROMED agreement — which focuses on manufactured products - to all industries by 2017 , without exclusion. As for the previous set of scenarios, an additional reform including a 25\% reduction of costs of trade across borders by 2017 is envisaged.

While the reforms can be assumed to be in force as from $2017^{7}$, the outcomes are given for the year 2020 in order for all variables of the model to properly adjust to shocks. Unless otherwise indicated, these annual outcomes are based on a comparison between the scenarios and the reference (or baseline; i.e. without trade reforms), either in percent or in absolute changes.

\section{Economic Impact of Implemented Reforms}

\section{A. Impact of different scenarios on export}

\section{Only the CFTA in place}

Implementation of the first scenario will have a significant impact on African countries' exports, which would significantly increase. North African exports would rise by $2.7 \%$ (or 8.9 billion US dollars), whereas the rest of Africa will experience an export increase of $8.2 \%$ (or 42.4 billion US dollars) in 2020 compared with the baseline (Table 1). The impact on other countries would remain very limited, as third countries (i.e., countries from outside Africa) would see their exports slightly decrease; for example, by a maximum of $0.2 \%$ in the case of the EU.

An increase in Africa's exports would essentially be the result of a boost in intraAfrican trade, which would expand (in absolute terms) by nearly 70 billion US dollars in 2020. North African exporters would receive as much as $20 \%$ of this gain (i.e., 13.6 billion US dollars), $52 \%$ of which would be attributable to an expansion in intra-North African trade alone (i.e., 7.1 billion US dollars) and the rest to increased exports by NACs to the rest of Africa (i.e., 6.5 billion US dollars). North African exports to the rest

Following the decision to tentatively establish a CFTA by 2017, all scenarios in this study are to be fully implemented by 2017 for consistency and comparisons made possible across scenarios. 
of the world would decrease by 4.7 billion US dollars (Appendix 4).

The reverse can be observed for the rest of Africa, where an increase in exports from one regional country to another ( +52 billion US dollars) is expected, which is considerably larger than their exports to North Africa (+3.8 billion US dollars) in absolute terms. Yet, in relative terms (i.e., percentage), exports from African countries (excluding North Africa) to North African economies would increase $(+114.3 \%)$ more than exports to each other $(+72.7 \%)$, owing to much larger increases in exports to North Africa, Central Africa, and Southern Africa than to their African partners outside North Africa (Appendix 3). In fact, in relative terms, all NACs, with the exception of Egypt, could expand their trade with African partners outside North Africa (this would be particularly evident in the case of Morocco).

Third countries would export less to African economies, redirecting some of their trade toward non-African partners; but in net, as indicated earlier, the CFTA reform would be slightly trade diverting for third countries. 
Table 1. Changes in total export

(in 2020)

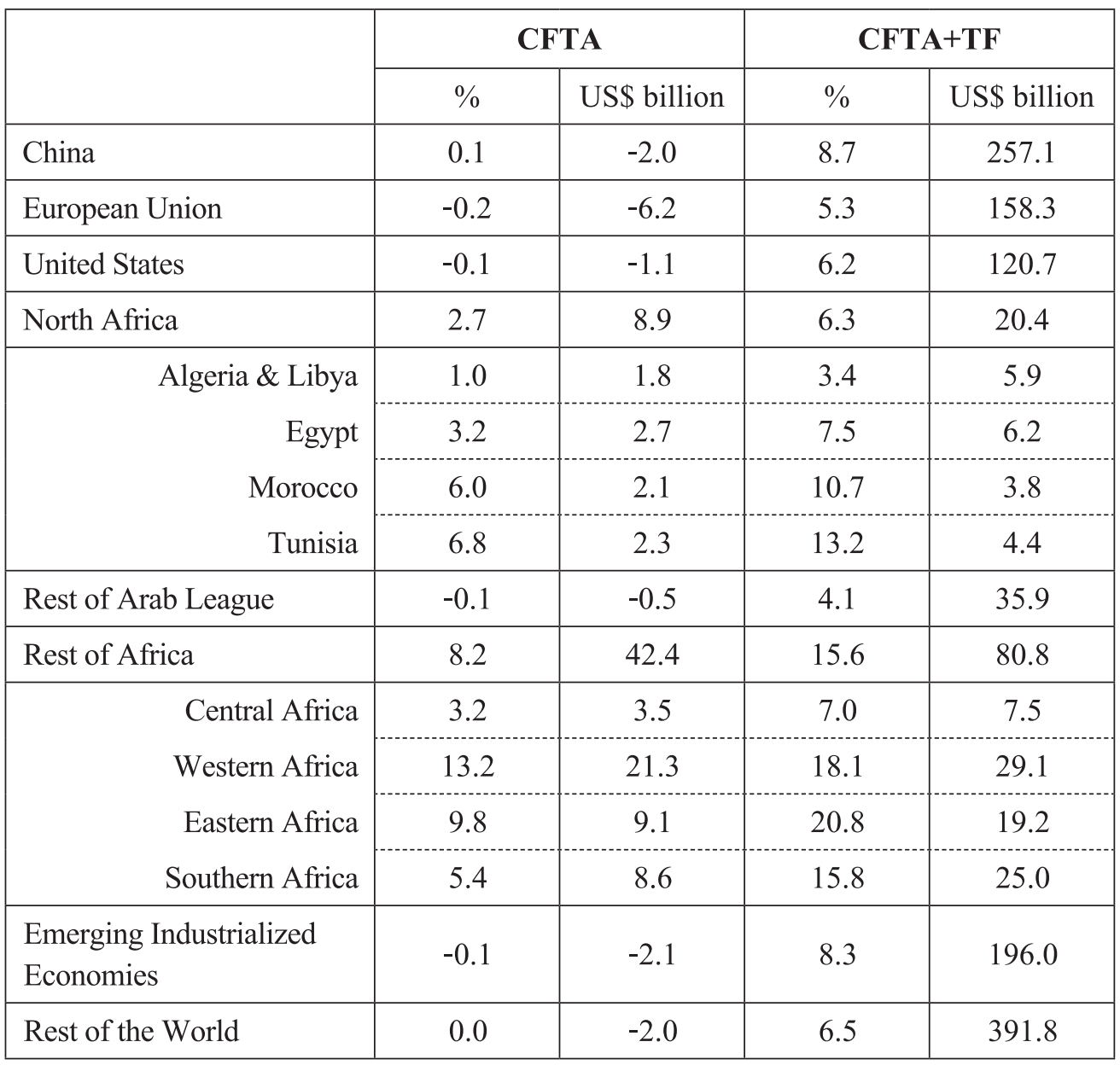

(Note) TF is trade facilitation measures.

(Source) Authors' calculations based on the MIRAGE model.

The improvement of trade-facilitation measures (i.e., reduced costs to trade across borders) would considerably enhance export gains for Africa and also stimulate exports for third countries, thereby reversing the negative effects these economies would experience from the CFTA reform alone.

Trade expansion can be observed for nearly all bilateral relationships; elsewhere, variations would be reduced thanks to trade facilitation reforms. It is also important to note that African countries (both North African and the rest of the continent) would be able to capture significant export opportunities not only within Africa, on account of 
the CFTA, but also outside of Africa because of trade-facilitation measures that would improve their competitiveness in foreign markets (Appendix 5 and Appendix 6).

As the primary change in exports following implementation of the CFTA relates to trade within the continent, we focus our analysis on changes in intra-African trade and intra-North-African trade by main sectors.

\section{Figure 1. Changes in intra-African trade}

(US\$ billion, in 2020)

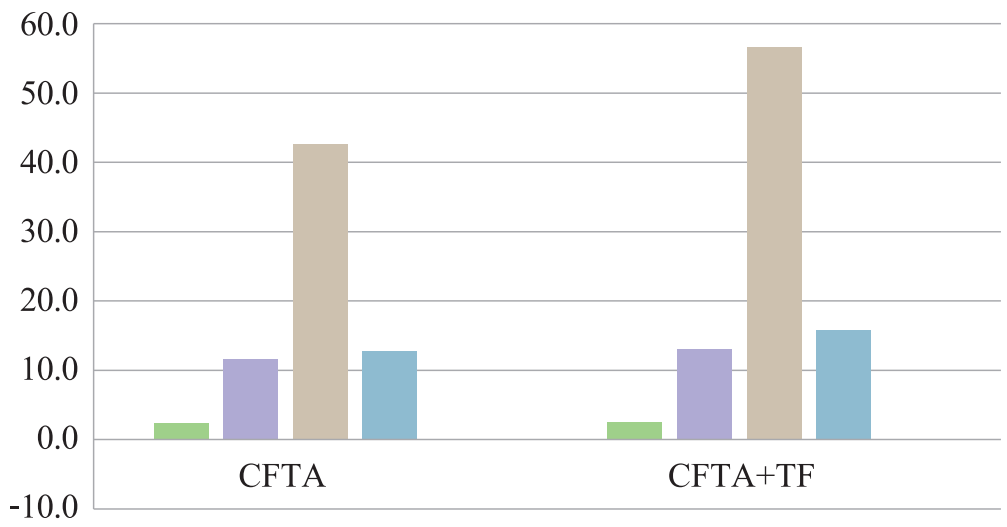

Agriculture $\square$ Food $\square$ Industry $\square$ Mining and energy $\square$ Services

(Note) TF is trade facilitation measures.

(Source) Authors' calculations based on the MIRAGE model.

In absolute terms (following the establishment of the CFTA), intra-African trade would see the biggest increases in industrial products ( 42.7 billion US dollars), bringing positive implications for Africa's industrialization. The industrial content of intra-African trade would expand further if trade-facilitation measures were improved in addition to the CFTA (at $61.5 \%$ and $64.3 \%$ of the increase in intra-African trade explained by industrial sectors alone following the introduction of the CFTA and CFTA + trade facilitation, respectively).

These results indicate that (1) the CFTA has a positive bias toward the industrial products trade and (2) trade-facilitation measures will increase trade of industrial products compared with other product categories (Figure 1). Indeed, trade-facilitation 
measures, in addition to the CFTA reform, will further increase intra-African trade of industrial products by 14 billion US dollars (21\%), whereas additional increases would only be 0.3 billion US dollars (1\%), USD 1.4 (19\%), and USD $3.1(14 \%)$ in agriculture, food, and mining and energy, respectively.

It should be stressed that initial trade conditions play an important role in shaping the results. The share of industrial products in intra-African trade tends to dominate, whereas exports from African countries to the rest of the world are largely skewed toward raw materials and energy commodities (Mevel and Karingi 2013). This also holds in the case of NACs (Appendix 7).

Furthermore, trade of intermediate products within the continent as well as with the rest of the world will increase, owing to trade-facilitation reforms, and will impact on the trade of final products. Trade-facilitation measures could have a significant impact on the incorporation into the global value chains as well, in addition to spurring the development of regional value chains across the continent or within North Africa; according to Portugal-Perez and Wilson (2010), trade facilitation can boost productivity.

Focusing solely on NACs' exports to all of Africa, the above conditions still hold; $59.0 \%$ and $61.4 \%$ of the increase in North African exports to all of Africa are concentrated in industrial sectors alone following implementation of the CFTA and the CFTA accompanied by efforts to facilitate trade across borders, respectively.

However, focusing only on intra-North African trade, the positive impact of the CFTA and trade facilitation reforms in industrialization would be much more pronounced (with about $68.8 \%$ and $69.7 \%$ of the increase in intra-African trade concentrated in industrial sectors alone following implementation of the CFTA without and with trade-facilitation reforms, respectively).

At the sector level, although crude and processed oil represent a significant share (namely 10\%) of the increase in intra-North African trade following CFTA reforms, the largest expansion would be for industrial products - chemicals, metals, and motor vehicles and parts - and machinery equipment; the increase in processed foods would also be significant for vegetable oils, dairy products, and other food products (Figure 2).

The adoption of trade-facilitation measures would favor most intra-North African trade in vegetable oils, mining, paper products, chemicals, metals, and electronic equipment; intra-trade in those industries would increase by at least an additional $25 \%$ with a reduction of costs to trade across borders compared with conditions in the CFTA without trade facilitation. 


\section{Figure 2. Changes in intra-North African trade}

(US\$ billion, in 2020)

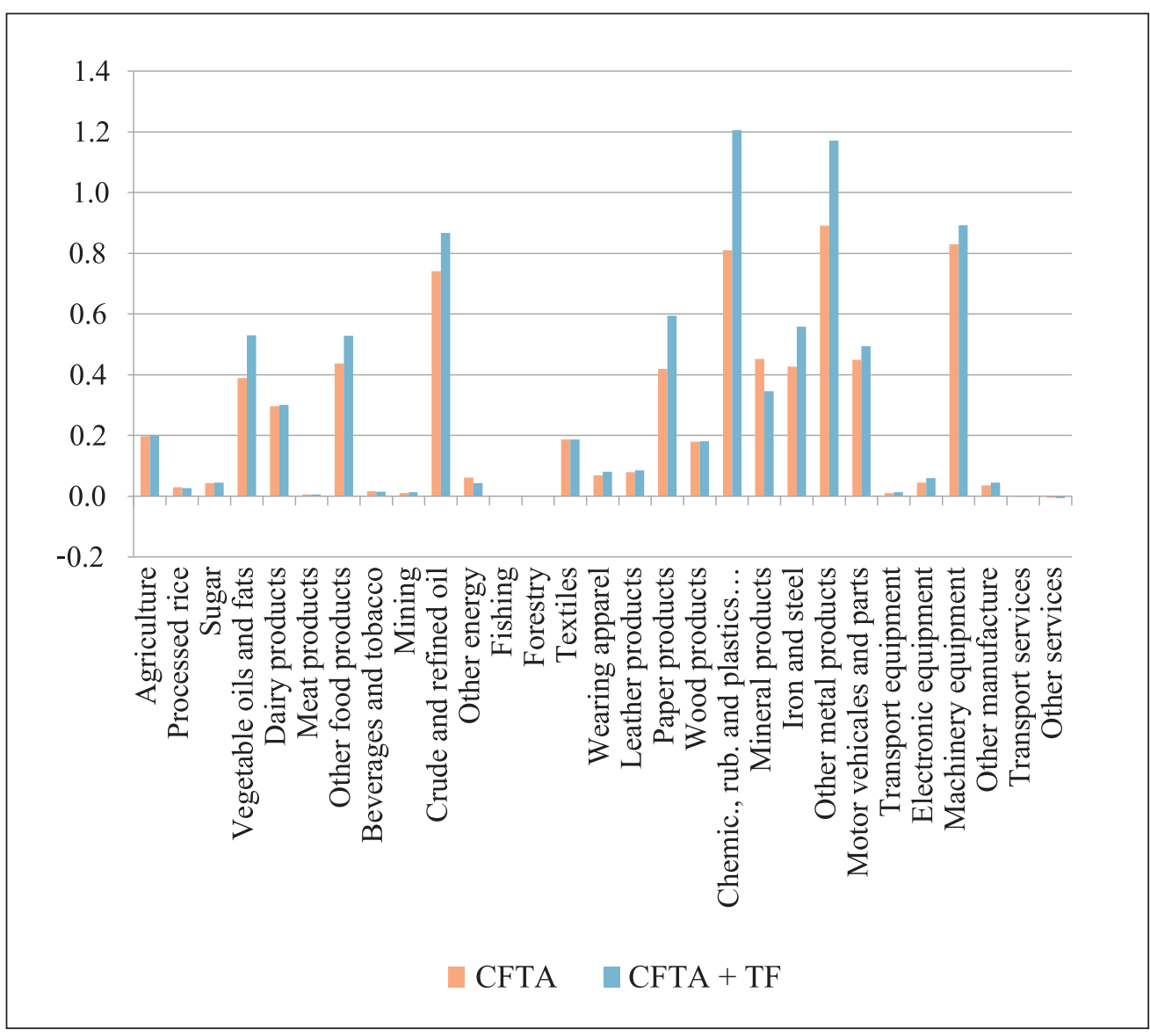

(Note) TF is trade facilitation measures.

(Source) Authors' calculations based on the MIRAGE model

\section{Pan-Arab FTA + CFTA in place}

The second set of scenarios implies an additional FTA with Arab League countries in addition to the CFTA. Against this background, the significant increase in intra-African trade attributable to the CFTA is complemented by a substantial increase in intra-Arab League trade (i.e., North Africa plus the rest of the Arab League), which would expand (in absolute terms) by nearly 15 billion US dollars in 2020. Export benefits for NACs alone 
would rise by an additional 3.8 billion US dollars compared with the scenario wherein only the CFTA is in place (i.e., 12.7 billion US dollars with both Pan-Arab FTA and CFTA versus 8.9 billion US dollars with only the CFTA). Countries from the rest of the Arab League would shift from a net trade diversion situation under the CFTA alone to a net trade creation situation if a Pan-Arab FTA is established in addition to the CFTA reform.

The trade diversion for intra-African trade is very limited (based on the fact that some NACs tend to export more to the rest of the Arab League at the expense of exports to partners from North Africa as well as the rest of Africa): intra-African trade would increase by 69.5 billion US dollars and 68.9 billion US dollars with the CFTA and the CFTA plus the Pan-Arab FTA, respectively. Third-party countries' exports to the Arab League (North Africa and rest of the Arab League) would drop further (compared with the situation wherein only the CFTA is implemented), but this trade diversion effect for third-party countries would remain fairly limited.

Trade facilitation would considerably expand the benefits for all Arab League countries, whereas for other countries (i.e., those outside the Arab League), benefits from trade facilitation would remain nearly unchanged compared with those enjoyed under the CFTA reform alone.

As far as intra-Arab League trade is concerned, a Pan-Arab FTA would drive industrial products the most. However, it is worth noting that if the CFTA stimulates intra-African trade in food products more than in mining/energy and agriculture, a PanArab FTA would stimulate intra-Arab League trade in mining and energy significantly more than in food and agricultural products. This would specifically be driven by (1) the sharp increase in mining and energy exports from North Africa to the rest of the Arab League following the implementation of the Pan-Arab FTA (Figure 3), (2) a significant increase in the rest of the Arab League countries' exports to NACs, and (3) a noticeable increase in intra-Rest of Arab League's (excluding NACs) trade in mining and energy. 
Figure 3. Changes in North African countries' exports to the Arab League

(US\$ billion, in 2020)

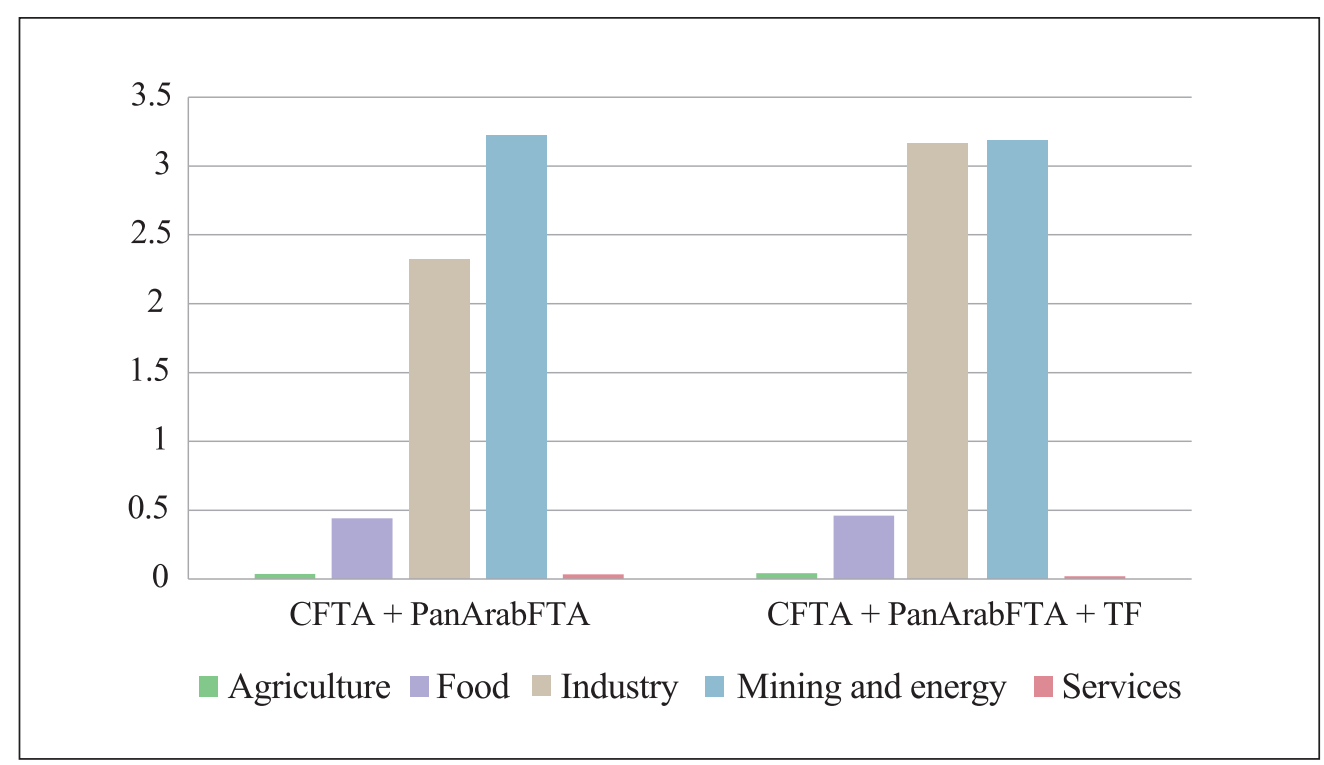

(Note) TF is trade facilitation measures.

(Source) Authors' calculations based on the MIRAGE model.

Intra-North African trade gains would, as mentioned earlier, only fall slightly if the Pan-Arab FTA were introduced in addition to the CFTA, simply because NACs would seize export opportunities from the rest of the Arab League, thereby increasing their exports to their North African counterparts and to their counterparts from the rest of Africa to a lesser extent than with the implementation of the CFTA only. Yet, this would not undermine the industrialization of intra-North African trade with or without tradefacilitation measures (Figure 4). 
Figure 4. Changes in intra-North African trade

(US\$ billion, in 2020)

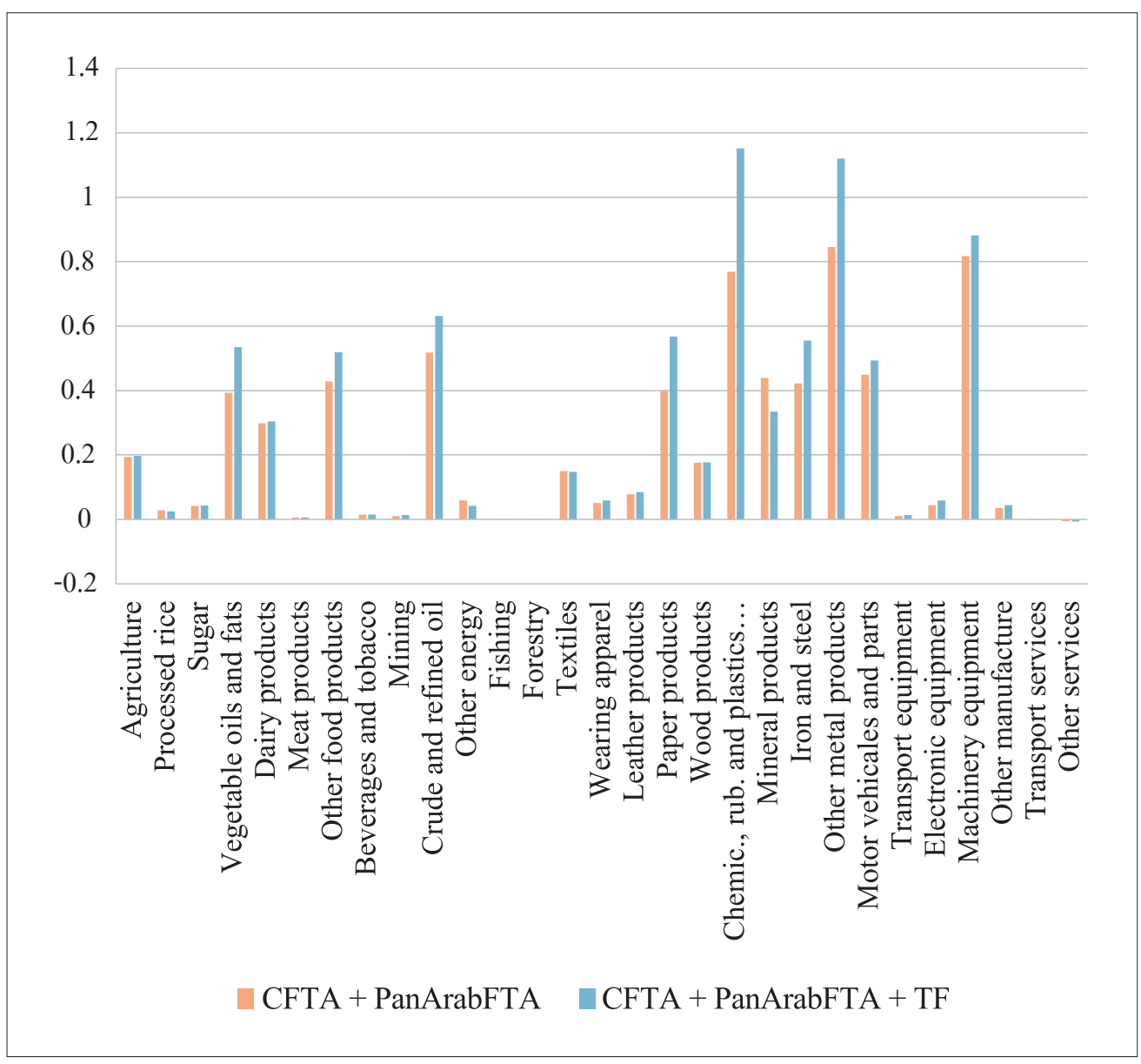

(Note) TF is trade facilitation measures.

(Source) Authors' calculations based on the MIRAGE model.

Next, analyzing the trade within the rest of the Arab League, industrial products would also see particular stimulation, and the benefits of having a Pan-Arab FTA in place are clear. Benefits for mining and energy products in intra-trade expansion (as highlighted earlier) are also evident; it is interesting to note that trade-facilitation measures matter tremendously for intra-Arab League trade in industrial products (as this sector makes the most impressive progress in relative terms with additional tradefacilitation reforms than without). This result confirms, in a more pronounced way, the previous result in the case of the introduction of the CFTA together with trade- 
facilitation measures.

\section{EUROMED FTA + CFTA and Pan-Arab FTA}

If a EUROMED FTA were established in addition to both CFTA and Pan-Arab FTA, trade creation would become significant. More precisely, exports to the EU and all other countries of the Mediterranean alliance would rise considerably. Exports from the EU would move from a contraction of about 8 billion US dollars with the introduction of the CFTA plus the Pan-Arab FTA to 36 billion US dollars if a EUROMEDFTA were also established. Export benefits would nearly quadruple for North Africa as a whole (in absolute terms, with the largest expansions for Morocco and Tunisia) compared with a situation wherein only CFTA and Pan-Arab FTA are in place. The larger the free trade area, the greater the export gains would be for North Africa; trade-facilitation measures would further compound the benefits, with export gains in industrial products always the highest in absolute terms. However, in the case of the Arab League - as seen previously, albeit much more pronounced under EUROMED - the share of industrial exports is considerably reduced due to the sizeable increase in North Africa's exports of food as well as energy and mining (Figure 5). 
Figure 5. Changes in North Africa's total exports

(US\$ billion, in 2020)

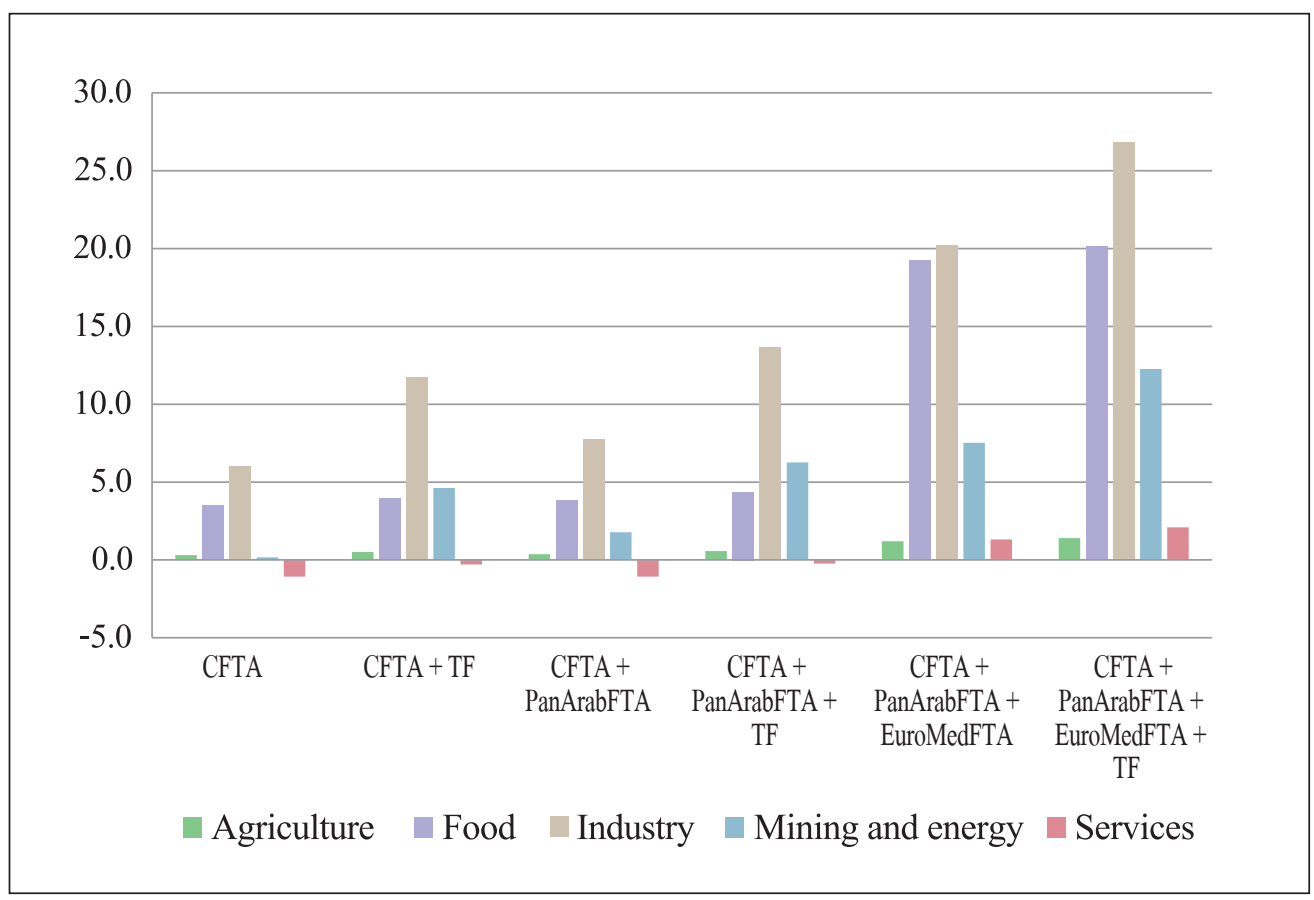

(Note) TF is trade facilitation measures.

(Source) Authors' calculations based on the MIRAGE model.

The remaining countries that are part of EUROMED would register relatively more limited additional gains in terms of their exports (in particular, countries from the rest of the Arab League) from the benefits already derived from the CFTA and the Pan-Arab FTA.

Given the relevant size effect, countries outside EUROMED would witness a decline in exports compared with the CFTA and Pan-Arab FTA following increased trade and higher competition within the EUROMED area. 
Table 2. Changes in total exports

(US\$ billion, in 2020)

\begin{tabular}{|c|c|c|c|c|c|c|}
\hline & CFTA & $\begin{array}{c}\text { CFTA }+ \\
\text { TF }\end{array}$ & $\begin{array}{c}\text { CFTA+ } \\
\text { PanArabFTA }\end{array}$ & $\begin{array}{c}\text { CFTA }+ \\
\text { PanArabFTA }+ \\
\text { TF }\end{array}$ & $\begin{array}{c}\text { CFTA+ } \\
\text { PanArabFTA+ } \\
\text { EuroMedFTA }\end{array}$ & $\begin{array}{c}\text { CFTA }+ \\
\text { PanArabFTA }+ \\
\text { EuroMedFTA }+ \\
\text { TF } \\
\end{array}$ \\
\hline China & -2.0 & 257.1 & -2.7 & 256.3 & -4.8 & 254.0 \\
\hline European Union & -6.2 & 158.3 & -8.1 & 156.2 & 36.0 & 202.6 \\
\hline United States & -1.1 & 120.7 & -1.4 & 120.3 & -3.3 & 118.4 \\
\hline North Africa & 8.9 & 20.4 & 12.7 & 24.5 & 49.2 & 62.2 \\
\hline Algeria \& Libya & 1.8 & 5.9 & 2.4 & 6.6 & 7.2 & 11.7 \\
\hline Egypt & 2.7 & 6.2 & 4.9 & 8.7 & 12.7 & 16.7 \\
\hline Morocco & 2.1 & 3.8 & 2.8 & 4.5 & 15.5 & 17.7 \\
\hline Tunisia & 2.3 & 4.4 & 2.6 & 4.8 & 13.8 & 16.3 \\
\hline Rest of Arab League & -0.5 & 35.9 & 11.2 & 48.5 & 12.3 & 49.5 \\
\hline Rest of Africa & 42.4 & 80.8 & 42.6 & 81.1 & 42.3 & 80.7 \\
\hline Central Africa & 3.5 & 7.5 & 3.5 & 7.5 & 3.4 & 7.4 \\
\hline Western Africa & 21.3 & 29.1 & 21.3 & 29.1 & 21.3 & 29.2 \\
\hline Eastern Africa & 9.1 & 19.2 & 9.4 & 19.6 & 9.3 & 19.5 \\
\hline Southern Africa & 8.6 & 25.0 & 8.5 & 24.9 & 8.2 & 24.7 \\
\hline $\begin{array}{l}\text { Emerging Industrialized } \\
\text { Economies }\end{array}$ & -2.1 & 196.0 & -3.0 & 195.1 & -2.7 & 195.5 \\
\hline Rest of the World & -2.0 & 391.8 & -3.6 & 390.1 & -5.8 & 387.7 \\
\hline
\end{tabular}

(Note) TF is trade facilitation measures.

(Source) Authors' calculations based on the MIRAGE model.

As observed in other scenarios, trade facilitation would play a very positive role in all countries' trade, expanding gains for EUROMED countries and more than compensating others for possible trade diversions (Table 2). For NACs, each FTA seems likely to stimulate, in relative terms, different main sectors. The breakdown by destination can help better understand these aspects (Table 3). Industrial products represent the largest share of North Africa's export gains to Africa (North Africa as well as the rest of Africa), whereas mining and energy dominate North Africa's export gains to the rest of the Arab League; and food dominates North Africa's exports to the EU. 
Table 3. Changes in exports from North Africa to main destinations

$(\%$, in 2020$)$

\begin{tabular}{|c|c|c|c|c|c|c|}
\hline & CFTA & $\begin{array}{c}\text { CFTA+ } \\
\text { TF }\end{array}$ & $\begin{array}{c}\text { CFTA }+ \\
\text { PanArabFTA }\end{array}$ & $\begin{array}{c}\text { CFTA }+ \\
\text { PanArabFTA } \\
+ \text { TF }\end{array}$ & $\begin{array}{c}\text { CFTA }+ \\
\text { PanArabFTA }+ \\
\text { EuroMedFTA }\end{array}$ & $\begin{array}{c}\text { CFTA }+ \\
\text { PanArabFTA }+ \\
\text { EuroMedFTA }+ \\
\text { TF }\end{array}$ \\
\hline & \multicolumn{6}{|c|}{ North Africa's exports to EU } \\
\hline Agricultural & -0.1 & 0.1 & -0.1 & 0.1 & 0.6 & 0.8 \\
\hline Food & -0.1 & 0.0 & -0.1 & 0.0 & 14.6 & 15.1 \\
\hline Industry & -1.5 & 1.3 & -1.3 & 1.6 & 8.2 & 11.9 \\
\hline Mining and energy & -0.6 & 2.9 & -1.2 & 2.3 & 3.1 & 6.8 \\
\hline Services & -0.4 & 0.0 & -0.4 & 0.0 & 0.6 & 1.0 \\
\hline \multirow[t]{2}{*}{ Total } & -2.8 & 4.3 & -3.2 & 4.0 & 27.1 & 35.6 \\
\hline & \multicolumn{6}{|c|}{ North Africa's exports to North African partners } \\
\hline Agricultural & 0.2 & 0.2 & 0.2 & 0.2 & 0.1 & 0.1 \\
\hline Food & 1.2 & 1.5 & 1.2 & 1.4 & 0.9 & 1.1 \\
\hline Industry & 4.9 & 5.9 & 4.7 & 5.7 & 2.7 & 3.4 \\
\hline Mining and energy & 0.8 & 0.9 & 0.6 & 0.7 & 0.2 & 0.3 \\
\hline Services & 0.0 & 0.0 & 0.0 & 0.0 & 0.0 & 0.0 \\
\hline \multirow[t]{2}{*}{ Total } & 7.1 & 8.5 & 6.7 & 8.0 & 3.9 & 4.9 \\
\hline & \multicolumn{6}{|c|}{ North Africa's exports to rest of Africa } \\
\hline Agricultural & 0.3 & 0.3 & 0.3 & 0.3 & 0.3 & 0.3 \\
\hline Food & 2.5 & 2.6 & 2.5 & 2.6 & 3.2 & 3.3 \\
\hline Industry & 3.2 & 3.7 & 3.2 & 3.7 & 4.3 & 4.9 \\
\hline Mining and energy & 0.6 & 0.6 & 0.6 & 0.6 & 0.6 & 0.6 \\
\hline Services & 0.0 & 0.0 & 0.0 & 0.0 & 0.0 & 0.0 \\
\hline \multirow[t]{2}{*}{ Total } & 6.5 & 7.1 & 6.5 & 7.2 & 8.4 & 9.1 \\
\hline & \multicolumn{6}{|c|}{ North Africa's exports to rest of Arab League } \\
\hline Agricultural & 0.0 & 0.0 & 0.0 & 0.0 & 0.0 & 0.0 \\
\hline Food & -0.1 & 0.0 & 0.3 & 0.3 & 0.4 & 0.5 \\
\hline Industry & -0.1 & 0.5 & 1.6 & 2.3 & 2.3 & 3.2 \\
\hline Mining and energy & -0.1 & 0.0 & 3.3 & 3.3 & 3.2 & 3.2 \\
\hline Services & 0.0 & -0.1 & 0.0 & 0.0 & 0.0 & 0.0 \\
\hline Total & -0.3 & 0.4 & 5.2 & 5.9 & 6.1 & 6.9 \\
\hline
\end{tabular}

(Note) TF is trade facilitation measures.

(Source) Authors' calculations based on the MIRAGE model. 


\section{B. Changes in tariff revenues and real incomes}

Tariff liberalization reforms imply relatively large cuts in tariff revenues, especially for NACs (Table 4). However, this impact differs from one country to another. While Algeria and Libya are the most negatively affected countries if the CFTA and the PanArab FTA are established, the tariff revenue impact is the most negative for Morocco and Tunisia in the event of EUROMED's establishment. The impact is more than 10 times greater for the entire region if EUROMED is implemented $(-58.8 \%)$, compared with the consequences of only the CFTA being established (-5.6\%); a Pan-Arab FTA would only double the fiscal impact compared with the situation with the CFTA reform alone, and Morocco would feel a strong impact. This is consistent with efforts to pursue this scenario, as the deeper the FTA reforms, the larger the liberalization efforts and the greater the drop in tariff revenues.

Table 4. Changes in tariff revenues

$(\%$, in 2020)

\begin{tabular}{|r|c|c|c|c|c|c|}
\hline & CFTA & $\begin{array}{c}\text { CFTA+ } \\
\text { TF }\end{array}$ & $\begin{array}{c}\text { CFTA+ } \\
\text { PanArabFTA }\end{array}$ & $\begin{array}{c}\text { CFTA+ } \\
\text { PanArabFTA+ } \\
\text { TF }\end{array}$ & $\begin{array}{c}\text { CFTA+ } \\
\text { PanArabFTA+ } \\
\text { EuroMedFTA }\end{array}$ & $\begin{array}{c}\text { CFTA+ } \\
\text { PanArabFTA+ } \\
\text { EuroMedFTA+ } \\
\text { TF }\end{array}$ \\
\hline European Union & -0.1 & 4.8 & -0.1 & 4.7 & -1.3 & 3.4 \\
\hline North Africa & -5.6 & -3.8 & -10.3 & -8.9 & -58.8 & -58.2 \\
\hline Algeria \& Libya & -11.5 & -10.6 & -15.5 & -15.0 & -44.6 & -44.2 \\
\hline Egypt & -1.8 & 1.2 & -6.5 & -4.2 & -56.7 & -55.1 \\
\hline Morocco & -2.6 & -1.5 & -9.2 & -8.2 & -71.9 & -72.0 \\
\hline Tunisia & -1.3 & 2.5 & -5.1 & -1.6 & -74.7 & -74.0 \\
\hline Rest of Arab League & -0.1 & 1.4 & -7.5 & -6.4 & -13.7 & -12.6 \\
\hline Rest of Africa & -25.3 & -21.7 & -25.6 & -22.0 & -26.4 & -22.7 \\
\hline Central Africa & -31.5 & -30.0 & -31.5 & -30.0 & -32.0 & -30.6 \\
\hline Western Africa & -33.4 & -30.6 & -33.4 & -30.6 & -34.5 & -31.7 \\
\hline Eastern Africa & -29.4 & -26.2 & -30.5 & -27.3 & -30.8 & -27.7 \\
\hline Southern Africa & 7.2 & 15.4 & 7.1 & 15.3 & 6.4 & 14.5 \\
\hline
\end{tabular}

(Note) TF is trade facilitation measures.

(Source) Authors' calculations based on the MIRAGE model. 
The implementation of trade-facilitation measures will, however, reduce the relatively negative tariff revenue impact in all scenarios. This is not surprising as trade-facilitation measures envisaged in the modeling exercise partly aim at improving cross-border (including customs) procedures, thereby making tariff revenue collection more efficient. Indeed, if trade-facilitation measures were implemented alone (i.e., without any of the tariff cuts implied by regional integration reforms), then trade would be boosted and tariff revenues would increase following the improvement of customs procedures and revenue collection. While NACs are expected to implement liberalization reforms in the context of the CFTA, GAFTA, and EUROMED, alongside the adoption of measures to facilitate trade across borders with all partners in conformity with the WTO Bali agreement, revenue collection will improve, especially vis-à-vis partners that will remain outside regional trade arrangements to which North Africa will not be (immediately) granting preferential market access. ${ }^{8}$ The reduction of the relatively negative tariff revenue effect through the adoption of trade-facilitation measures is particularly pronounced in the case of CFTA reforms alone, as customs procedures are often less efficient within Africa than between Africa and the rest of the world.

This negative effect does not considerably impact real incomes, which are either only slightly negative or slightly positive, depending on the trade reforms; however, adoption of trade-facilitation measures has positive impacts on all countries' real income level and even offsets possible negative effects of liberalization reforms (Table 5), particularly given large trade gains leading to improved terms of trade and reallocation of resources toward the most efficient factors of production as well as improved tariff revenue collection.

\footnotetext{
${ }^{8}$ In the case of Nepal's or Pakistan's custom reforms, annual customs revenue grew significantly following the reforms (www. wbginvestmentclimate.org), despite drastically reduced tariffs. Angola, Bangladesh, Bolivia, Ghana, Mozambique, Peru, Uganda, and Jamaica experienced the same significant effect (Milner et al. 2008).
} 


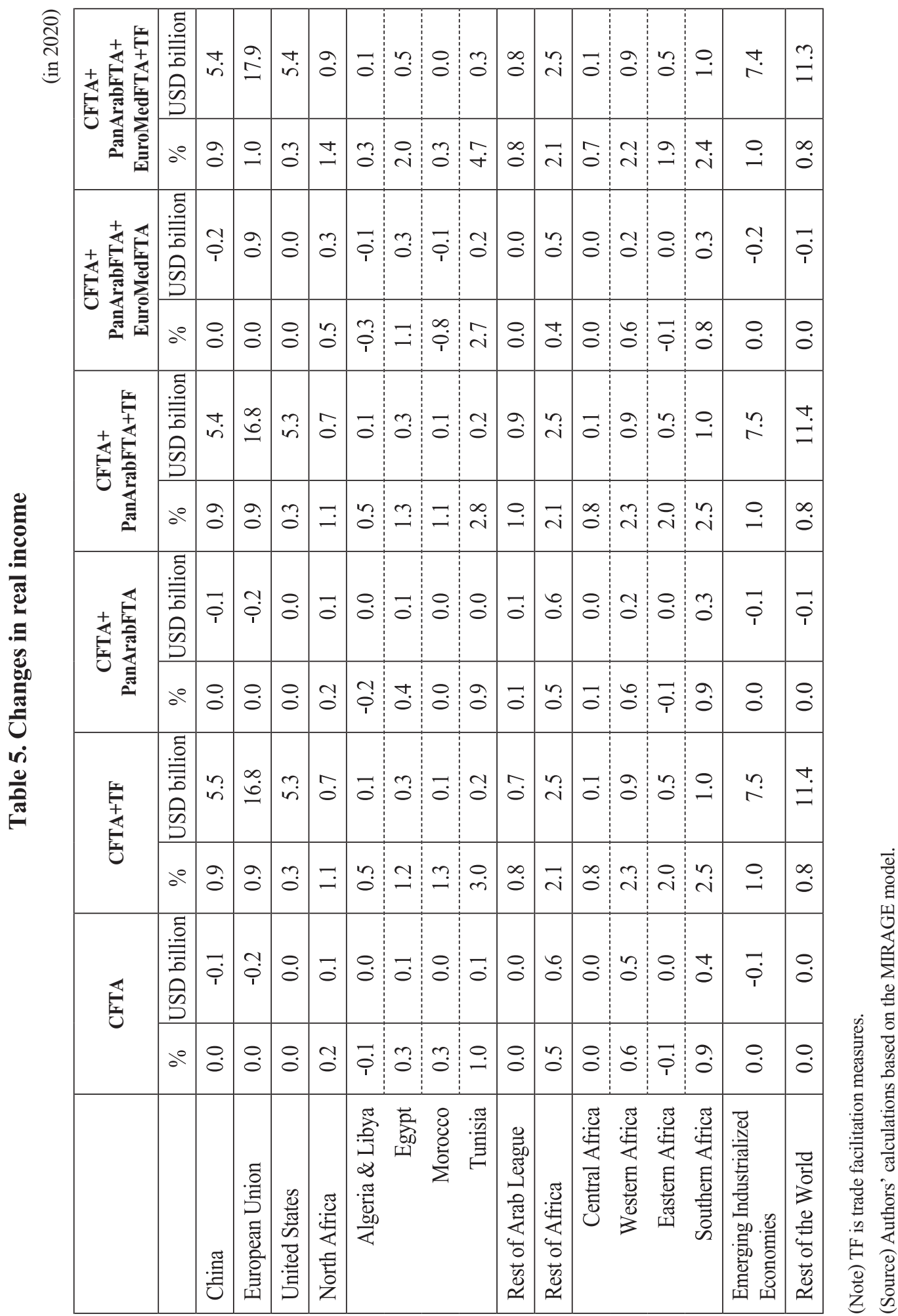


Moreover, it should be highlighted that any possible and relatively limited negative effects on real incomes in North African economies can potentially be offset through other fiscal reforms made possible by increases in trade volume and economic activity following the implementation of the various integration policies.

\section{Conclusions}

Across the different phases of their economic development, NACs have implemented various policies to promote structural transformation without significant success, particularly when their progress is compared with that made by East Asian developing countries. During the last decade, NACs have experienced stagnation in their manufacturing sectors and even undergone a certain degree of deindustrialization during the second part of this period. North Africa displays the highest level of MVA per capita among African regions at 276 US dollars, but its MVA accounts only for one-tenth of its GDP. In addition, the region's manufacturing sector continues to grow at a slower pace than its economy.

The importance of manufacturing remains high for the future economic growth of developing countries. A limited number of developing countries have managed in the last decades to expand their industrial sectors and concentrate significant shares of the developing grouping MVA (Haraguchi et al. 2016, UNIDO 2016). However, North Africa has not expanded its industrial base during the last decade. Its contribution to global manufacturing remains marginal (Upadhyaya and Mirzaei Yeganeh 2015). The region has not witnessed an emergence of a vibrant manufacturing sector underpinning regional economic growth and driving significant structural transformation. Rather, industrial development shows different paces and patterns within the region. Algeria's and Libya's reliance on natural resources indicates their urgent need to diversify their economies. Tunisia, Egypt, and Morocco have witnessed their larger manufacturing sectors stagnate or even decline in the recent past. The political and social changes in the region and their strong dependence on a reduced number of markets (notably, the EU), which were hit by the 2008 economic and financial crisis, partly explain such a mitigated industrial performance.

Trade policy can make significant contributions to improved outcomes, particularly 
to increased processing, to lead to higher value-added. Regional trade agreements may constitute a key instrument to raise participation of NACs in global trade. The African continent's positive growth prospects, related to the rapid urbanization and growth of the middle class, may convert the CFTA into a viable opportunity for North African economies to boost their manufactured exports. Given NACs' traditional trade relations with Europe and, to a lesser extent, with the remaining Arab countries, this assumption has been assessed as being well within the context of the GAFTA, including the countries of the League of Arab States, and the EUROMED process with the EU.

In this study, three sets of scenarios were empirically assessed using CGE modelling: (1) establishment of the CFTA without and with trade-facilitation reforms; (2) effective implementation of the GAFTA in the context of the CFTA without and with the adoption of trade-facilitation measures; and (3) fully operational EUROMED with GAFTA and CFTA also in place, without and with measures to facilitate cross-border trade.

Our findings indicate that, in absolute terms, CFTA's establishment would boost intra-African trade, with industrial products thereby being stimulated the most (with as much as 42.7 billion US dollars out of the 69.5 billion US dollars increase in intraAfrican trade found in industrial products alone), generating positive outcomes for Africa's industrialization. The industrial content of intra-African trade would expand further if trade-facilitation measures were improved in addition to the introduction of CFTA. Indeed, when trade-facilitation measures are adopted within the context of CFTA reform, intra-African trade in industrial products further increases by 14 billion US dollars. Focusing solely on the impact on intra-North African trade, the positive effects of CFTA and trade-facilitation reforms on industrialization would be even more pronounced.

A Pan-Arab FTA established in addition to the CFTA would further increase trade in industrial products for NACs as well as for other LAS countries. However, it is worth noting that the share of NACs' trade gains in industrial products would be noticeably reduced compared with those arising from the CFTA reform alone due to the strong increase in intra-Arab League trade (and especially exports and imports of NACs to/from Arab League partners) of not only mining/energy products but also food. In this case, trade-facilitation measures tremendously matter for North African trade of industrial products, as this sector could experience the largest progression if trade-facilitation reforms are adopted, in relative terms, when compared with a situation without trade facilitation.

When a EUROMED FTA is established along with both CFTA and Pan-Arab FTA, 
considerable additional trade is generated. More precisely, exports to the EU and all other countries of the Mediterranean alliance — in particular, from NACs — will generally rise tremendously, especially if cross-border trade costs fall. However, while North African exports of industrial products still increase most in absolute terms with the establishment of EUROMED on top of the CFTA and GAFTA, the share of industrial products in North Africa's export gains will shrink under the sharp increase in food exports from North Africa to the EU following the formation of the EUROMED FTA.

In other words, it appears that each FTA configuration will, in relative terms, stimulate North African countries' exports from different main industries most. Whereas industrial products represent the largest share of North Africa's export gains to Africa in general (North Africa as well as the rest of Africa), mining and energy dominate North Africa's export gains to the rest of the Arab League, while food dominates North Africa's exports to the EU. This is largely attributable to the currently very different trade structures between North Africa and its partners from Africa, the Arab League and the EU.

Therefore, the establishment of the CFTA, accompanied by trade-facilitation measures, appears to be crucial in supporting the industrialization of North African economies. Indeed, if the GAFTA and EUROMED were to be established without the CFTA in place, then the pro-industrialization effects would be much more marginal for North African economies. Obviously, regional integration reforms that offer clear newmarket opportunities for North African nations come with a cost, as they generate tariff revenue losses that can mitigate real income effects (some countries being affected more negatively than others). However, complementary policies such as adoption of tradefacilitation measures are critical to guaranteeing better distributed outcomes and real income gains for all NACs specifically and all African economies in general. These measures also help to boost further intra-regional trade and export-led industrialization considerably. These outcomes will, of course, only be possible if (1) adjustment efforts are made to tackle tariff revenue contractions at the country level (including efforts to limit illicit financial outflows through trade mispricing; see Mevel et al. 2014), (2) exemptions from trade liberalization efforts (such as so-called sensitive products) are prohibited or strictly limited, (3) reforms are fully implemented and effective, and (4) coordination is improved between trade and industrial policy. Furthermore, trade-facilitation reforms will have the maximum impact if an important endeavor is simultaneously undertaken in trade infrastructure (WTO 2015); highlighting the key importance of allocating financial resources devoted to these efforts. Generalizing 
the establishment of common funds and regional development banks to finance key infrastructure projects and other projects aiming at easing trade across borders will be of major importance, as they often benefit a large number of countries and facilitate the development of regional value chains. Against this background, aid for trade projects, in particular, should focus more on boosting intra-regional trade.

Received 16 February 2016, Revised 9 May 2016, Accepted 19 July 2016

\section{References}

Abarche, Jorge, S., Delfin S. Go and John Page, "Is Africa at a turning point?" Policy Research Working Paper 4519 (2008), Africa Region, Washington, The World Bank.

Ben Hammouda, Hakim, Nassim Oulmane, and Mustapha Sadni Jallab, "D'une diversification spontanée à une diversification organisée. Quelles politiques pour diversifier les économies d'Afrique du Nord ?" Revue économique, Presses de SciencesPo, vol. 60 (1) (2009): 133-155.

Bigsten, Arne and Måns Söderbom, "Industrial Strategies for Economic Recovery and Long-term Growth in Africa" African Development Review 23:2 (2011): 161-171.

Decreux, Yvan, and Hugo Valin, "MIRAGE, Updated Version of the Model for Trade Policy Analysis: Focus on Agricultural and Dynamics" CEPII, Working paper No. 200715 (2007).

Haraguchi, Nobuya, Charles F. Chin Cheng, and Eveline Smeets "The importance of manufacturing in economic development: Has this changed?" UNIDO Working Paper 01/2016 (2016), Vienna, Austria.

Hausmann, Ricardo, Jason Hwang, and Dany Rodrik, "What You Export Matters" Journal of Economic Growth 12(1) (2007): 1-25.

Imb, Jean and Romain Wacziarg, "Stages of diversification" American Economic Review, vol. 93, no. 1 (2003): 63-86. 
Karingi, Stephen N. and Malcom D. Spence, "Impact of trade facilitation mechanisms on export competitiveness in Africa" African Trade Policy Centre Work in Progress No. 84 (2011), UNECA, Addis Ababa, Ethiopia.

Lall, Sanjaya, “Is African industry competing?” Working Paper Number 121 (2005), Queen Elizabeth House, University of Oxford.

Mevel, Simon and Stephen Karingi, "Towards a Continental Free Trade Area in Africa - A CGE Modelling Assessment with a Focus on Agriculture" Chapter 8 in Shared Harvests: Agriculture, Trade and Employment (2013), ILO-UNCTAD, Geneva.

Mevel, Simon, Siope Ofa and Stephen Karingi, "Quantifying Illicit Financial Flows from Africa through Trade Mis-Pricing and Assessing their Incidence on African Economies" in Regional Integration and Policy Challenges in Africa, ed. A. Elhiraika, A. Mukungu, and W. Nyoike, (2014): 220-232, London, UK: Palgrave McMillan.

Milner, Chris, Oliver Morrissey, and Evious Zgovu, "Trade Facilitation in Developing Countries" CREDIT research Paper 08/05 (2008).

Minor, Peter and David Hummels, "Time as a Barrier to Trade: A GTAP Database of ad valorem Trade Time Costs" Latest version of the Research Report submitted to GTAP $11^{\text {th }}$ Annual Conference, Helsinki, Finland (2011).

Moll de Alba, Jaime, "Industrial development in North African countries -A statistical profile" UNIDO Working Paper 03/2014 (2014), Vienna, Austria.

Narayanan, G., Badri, A. Aguiar and R. McDougall, Eds. 2012. Global Trade, Assistance, and Production: The GTAP 8 Data Base, Center for Global Trade Analysis, Purdue University.

Page, John, “Can Africa Industrialize?” Journal of African Economies, Vol. 21, AERC Supplement 2, (2012): ii86-ii125.

Portugal-Perez, Alberto and John S. Wilson, "Export performance and trade facilitation reform: hard and soft infrastructure" Policy Research Working Paper Series 5261 (2010), The World Bank.

Szirmai, Adam, "Industrialisation as an engine of growth in developing countries, 19502005" Structural Change and Economic Dynamics, 3 (4) (2012): 406-420.

UNCTAD and UNIDO, Fostering Industrial Development in Africa in the New 
Global Environment, Economic Development in Africa Report 2011, United Nations publication, New York and Geneva (2011).

UNECA, Economic Report on Africa. Addis Ababa, Ethiopia (2014).

UNIDO, Breaking in and Moving up: New Industrial Challenges for the Bottom Billion and the Middle-income Countries, Industrial Development Report 2009, Vienna, Austria (2009).

UNIDO, The Industrial Competitiveness of Nations, Looking back, forging ahead, Competitive Industrial Performance Report 2012/2013, Vienna, Austria (2013a).

UNIDO, Sustaining Employment Growth: The Role of Manufacturing and Structural Change, Industrial Development Report 2013, Vienna, Austria (2013b).

UNIDO, The Role of Technology and Innovation in Inclusive and Sustainable Industrial Development, Industrial Development Report 2016, Vienna, Austria (2016).

Upadhyaya, S. and S. Mirzai Yeganeh, "Competitive Industrial Performance Report 2014" UNIDO Working Paper 12/2014 (2015), Vienna, Austria.

World Bank, Doing Business: Trading Across Borders, 2013 Report (2013).

World Trade Organization, "Speeding up trade benefits and challenging of implementing the WTO Trade Facilitation agreement" World Trade Report, Geneva, Switzerland (2015). 


\section{Appendix 1: Geographic decomposition for the modeling}

\begin{tabular}{|c|c|c|}
\hline & Country/Region & Main region \\
\hline 1 & Egypt & North Africa \\
\hline 2 & Morocco & North Africa \\
\hline 3 & Tunisia & North Africa \\
\hline 4 & Rest of North Africa (i.e. Algeria and Libya) & North Africa \\
\hline 5 & Central Africa & Rest of Africa \\
\hline 6 & Western Africa & Rest of Africa \\
\hline 7 & Eastern Africa & Rest of Africa \\
\hline 8 & Southern Africa & Rest of Africa \\
\hline 9 & Rest of Arab League & Rest of Arab League \\
\hline 10 & European Union & European Union (28 members) \\
\hline 11 & United States & United States \\
\hline 12 & China & China \\
\hline 13 & Emerging industrialized & Emerging industrialized economies \\
\hline 14 & Rest of the world & Rest of the world \\
\hline
\end{tabular}




\section{Appendix 2: Sectoral decomposition for the modeling}

\begin{tabular}{|c|c|c|}
\hline & Sector & Main sector \\
\hline 1 & Agriculture & Agriculture \\
\hline 2 & Dairy products & Processed food \\
\hline 3 & Meat products & Processed food \\
\hline 4 & Vegetable oils and fats & Processed food \\
\hline 5 & Processed rice & Processed food \\
\hline 6 & Sugar & Processed food \\
\hline 7 & Other food products & Processed food \\
\hline 8 & Beverages and tobacco & Processed food \\
\hline 9 & Other energy & Mining and energy \\
\hline 10 & Crude and refined oil & Mining and energy \\
\hline 11 & Mining & Mining and energy \\
\hline 12 & Fishing & Industry \\
\hline 13 & Forestry & Industry \\
\hline 14 & Textiles & Industry \\
\hline 15 & Wearing apparel & Industry \\
\hline 16 & Leather products & Industry \\
\hline 17 & Wood products & Industry \\
\hline 18 & Paper products & Industry \\
\hline 19 & Chemicals, rubber and plastic products & Industry \\
\hline 20 & Mineral products & Industry \\
\hline 21 & Iron and steel & Industry \\
\hline 22 & Other metal products & Industry \\
\hline 23 & Motor vehicles and parts & Industry \\
\hline 24 & Transport equipment & Industry \\
\hline 25 & Electronic equipment & Industry \\
\hline 26 & Machinery equipment & Industry \\
\hline 27 & Other manufacture & Industry \\
\hline 28 & Other services & Services \\
\hline 29 & Transport services & Services \\
\hline
\end{tabular}




\section{Appendix 3: Changes in bilateral trade, following the CFTA}

$(\%$, in 2020)

\begin{tabular}{|c|c|c|c|c|c|c|c|c|}
\hline & China & $\begin{array}{l}\text { European } \\
\text { Union }\end{array}$ & $\begin{array}{l}\text { United } \\
\text { States }\end{array}$ & $\begin{array}{l}\text { North } \\
\text { Africa }\end{array}$ & $\begin{array}{l}\text { Rest of } \\
\text { Arab } \\
\text { League }\end{array}$ & $\begin{array}{l}\text { Rest of } \\
\text { Africa }\end{array}$ & EIE & $\begin{array}{c}\text { Rest of } \\
\text { the World }\end{array}$ \\
\hline China & & 0.1 & 0.1 & -0.7 & 0.1 & -8.2 & 0.1 & 0.1 \\
\hline European Union & -0.1 & & 0.0 & 0.9 & 0.0 & -3.5 & 0.0 & 0.0 \\
\hline United States & -0.1 & 0.0 & & 0.4 & 0.0 & -1.7 & 0.0 & 0.0 \\
\hline North Africa & -1.5 & -1.6 & -0.7 & 73.1 & -2.6 & 126.1 & -1.3 & -2.2 \\
\hline Algeria \& Libya & -0.1 & 0.0 & 0.1 & 33.6 & 2.6 & 146.4 & 0.1 & 0.1 \\
\hline Egypt & -1.9 & -2.7 & -2.3 & 88.2 & -2.8 & 77.2 & -3.1 & -2.7 \\
\hline Morocco & -3.5 & -2.7 & -2.5 & 26.1 & -5.2 & 240.8 & -2.4 & -2.7 \\
\hline Tunisia & -6.8 & -6.2 & -6.4 & 116.1 & -6.3 & 127.4 & -5.9 & -6.2 \\
\hline Rest of Arab League & 0.0 & 0.0 & 0.2 & -0.5 & 0.1 & -4.4 & 0.1 & 0.0 \\
\hline Rest of Africa & -1.2 & -3.6 & -2.8 & 114.3 & -2.3 & 72.7 & -4.0 & -3.9 \\
\hline Central Africa & 0.5 & 1.7 & 0.6 & 165.9 & 1.6 & 62.8 & 0.9 & 1.0 \\
\hline Western Africa & -3.7 & -3.2 & -3.2 & 59.1 & -3.6 & 126.3 & -3.4 & -3.3 \\
\hline Eastern Africa & 1.0 & 2.4 & 1.1 & 38.8 & 3.5 & 39.6 & 1.9 & 2.2 \\
\hline Southern Africa & -6.1 & -8.6 & -9.5 & 284.6 & -9.5 & 58.1 & -10.3 & -9.0 \\
\hline $\begin{array}{l}\text { Emerging Industrialized } \\
\text { Economies }\end{array}$ & 0.0 & 0.1 & 0.1 & -1.5 & 0.0 & -6.6 & 0.1 & 0.1 \\
\hline Rest of the World & -0.1 & 0.0 & 0.0 & -0.6 & 0.0 & -1.3 & 0.0 & 0.0 \\
\hline
\end{tabular}

(Source) Authors' calculations based on the MIRAGE model. 


\section{Appendix 4: Changes in bilateral trade, following the CFTA reforms}

(US\$ billion, in 2020)

\begin{tabular}{|c|c|c|c|c|c|c|c|c|}
\hline & China & $\begin{array}{l}\text { European } \\
\text { Union }\end{array}$ & $\begin{array}{l}\text { United } \\
\text { States }\end{array}$ & $\begin{array}{l}\text { North } \\
\text { Africa }\end{array}$ & $\begin{array}{c}\text { Rest of } \\
\text { Arab } \\
\text { League }\end{array}$ & $\begin{array}{l}\text { Rest of } \\
\text { Africa }\end{array}$ & EIE & $\begin{array}{c}\text { Rest of } \\
\text { the World }\end{array}$ \\
\hline China & & 1.1 & 0.8 & -0.2 & 0.1 & -5.5 & 0.3 & 1.4 \\
\hline European Union & -0.2 & & 0.2 & -1.1 & 0.0 & -5.2 & -0.1 & 0.2 \\
\hline United States & -0.2 & 0.0 & & 0.1 & 0.0 & -0.6 & -0.2 & -0.1 \\
\hline North Africa & -0.2 & -2.8 & -0.3 & 7.1 & -0.3 & 6.5 & -0.5 & -0.6 \\
\hline Algeria \& Libya & 0.0 & 0.0 & 0.0 & 1.2 & 0.0 & 0.5 & 0.0 & 0.0 \\
\hline Egypt & -0.1 & -0.9 & -0.2 & 2.4 & -0.2 & 2.3 & -0.3 & -0.3 \\
\hline Morocco & -0.1 & -0.5 & -0.1 & -0.2 & -0.0 & 2.9 & -0.1 & -0.1 \\
\hline Tunisia & 0.0 & -1.4 & -0.1 & 3.3 & 0.0 & 0.8 & -0.1 & -0.2 \\
\hline Rest of Arab League & 0.0 & 0.0 & 0.2 & -0.1 & 0.0 & -1.0 & 0.2 & 0.2 \\
\hline Rest of Africa & -1.0 & -4.5 & -2.8 & 3.8 & -0.3 & 52.0 & -2.3 & -2.7 \\
\hline Central Africa & 0.2 & 0.3 & 0.2 & 0.4 & 0.0 & 2.2 & 0.1 & 0.1 \\
\hline Western Africa & -0.4 & -1.2 & -1.6 & 0.7 & -0.1 & 25.3 & -1.0 & -0.4 \\
\hline Eastern Africa & 0.2 & 0.6 & 0.1 & 0.5 & 0.2 & 7.2 & 0.1 & 0.4 \\
\hline Southern Africa & -1.0 & -4.1 & -1.4 & 2.3 & -0.4 & 17.3 & -1.4 & -2.7 \\
\hline $\begin{array}{l}\text { Emerging Industrialized } \\
\text { Economies }\end{array}$ & 0.0 & 0.5 & 0.7 & -0.5 & 0.0 & -3.5 & 0.1 & 0.5 \\
\hline Rest of the World & -0.1 & 0.0 & 0.3 & -0.2 & 0.0 & -1.0 & -0.1 & 0.0 \\
\hline
\end{tabular}

(Source) Authors' calculations based on the MIRAGE model. 


\section{Appendix 5: Changes in trade after the CFTA reforms with trade-facilitation}

$(\%$, in 2020)

\begin{tabular}{|c|c|c|c|c|c|c|c|c|}
\hline & China & $\begin{array}{l}\text { European } \\
\text { Union }\end{array}$ & $\begin{array}{l}\text { United } \\
\text { States }\end{array}$ & $\begin{array}{l}\text { North } \\
\text { Africa }\end{array}$ & $\begin{array}{c}\text { Rest of } \\
\text { Arab } \\
\text { League }\end{array}$ & $\begin{array}{l}\text { Rest of } \\
\text { Africa }\end{array}$ & EIE & $\begin{array}{l}\text { Rest of } \\
\text { the World }\end{array}$ \\
\hline China & & 8.9 & 5.6 & 7.0 & 7.2 & 6.0 & 13.9 & 9.7 \\
\hline European Union & 8.7 & & 3.1 & 3.2 & 1.9 & 0.8 & 7.3 & 5.9 \\
\hline United States & 9.9 & 3.9 & & 1.7 & 2.1 & 2.5 & 7.3 & 6.7 \\
\hline North Africa & -0.6 & 2.5 & 0.8 & 87.0 & 3.1 & 137.9 & 0.2 & -0.2 \\
\hline Algeria \& Libya & -3.2 & 2.9 & 1.4 & 38.2 & 10.3 & 151.5 & 4.3 & -1.2 \\
\hline Egypt & 4.5 & 3.1 & -0.9 & 101.8 & 3.3 & 91.5 & -5.8 & 0.6 \\
\hline Morocco & 1.6 & 3.2 & 0.6 & 39.3 & -3.4 & 247.7 & -4.2 & 1.8 \\
\hline Tunisia & -3.6 & -0.7 & -4.0 & 142.3 & -4.2 & 139.5 & -5.9 & -4.7 \\
\hline Rest of Arab League & 3.5 & 5.4 & -0.2 & 9.6 & 14.9 & 5.7 & 0.9 & 4.0 \\
\hline Rest of Africa & 2.8 & 3.1 & 0.8 & 131.5 & 3.0 & 95.2 & -2.0 & 4.3 \\
\hline Central Africa & 3.1 & 9.5 & 3.9 & 228.4 & 13.4 & 69.4 & 2.1 & 3.5 \\
\hline Western Africa & -0.5 & 3.2 & -0.2 & 67.9 & -2.3 & 136.7 & -2.4 & 7.8 \\
\hline Eastern Africa & 7.0 & 9.0 & 7.3 & 55.5 & 12.6 & 66.6 & 7.7 & 11.3 \\
\hline Southern Africa & 0.5 & -1.8 & -4.6 & 301.7 & -8.5 & 87.7 & -7.2 & -0.8 \\
\hline $\begin{array}{l}\text { Emerging Industrialized } \\
\text { Economies }\end{array}$ & 9.9 & 5.9 & 5.8 & 2.6 & 5.3 & 3.1 & 13.6 & 10.6 \\
\hline Rest of the World & 10.2 & 3.7 & 4.9 & 1.4 & 4.2 & 2.7 & 8.9 & 6.2 \\
\hline
\end{tabular}

(Source) Authors' calculations based on the MIRAGE model. 


\section{Appendix 6: Changes in trade after the CFTA reforms with trade-facilitation}

(US\$ billion, in 2020)

\begin{tabular}{|c|c|c|c|c|c|c|c|c|}
\hline & China & $\begin{array}{c}\text { European } \\
\text { Union }\end{array}$ & $\begin{array}{l}\text { United } \\
\text { States }\end{array}$ & $\begin{array}{l}\text { North } \\
\text { Africa }\end{array}$ & $\begin{array}{c}\text { Rest of } \\
\text { Arab } \\
\text { League }\end{array}$ & $\begin{array}{c}\text { Rest } \\
\text { of } \\
\text { Africa }\end{array}$ & EIE & $\begin{array}{l}\text { Rest } \\
\text { of the } \\
\text { World }\end{array}$ \\
\hline China & & 63.2 & 41.8 & 2.2 & 5.6 & 4.0 & 42.6 & 97.9 \\
\hline European Union & 29.0 & & 18.1 & 3.8 & 3.3 & 1.2 & 37.5 & 65.3 \\
\hline United States & 19.4 & 17.3 & & 0.4 & 1.4 & 0.9 & 26.9 & 54.4 \\
\hline North Africa & -0.1 & 4.3 & 0.4 & 8.5 & 0.4 & 7.1 & 0.1 & -0.1 \\
\hline Algeria \& Libya & -0.2 & 2.8 & 0.5 & 1.3 & 0.1 & 0.5 & 1.0 & -0.1 \\
\hline Egypt & 0.1 & 1.0 & -0.1 & 2.8 & 0.3 & 2.7 & -0.7 & 0.1 \\
\hline Morocco & 0.0 & 0.6 & 0.0 & 0.3 & 0.0 & 3.0 & -0.2 & 0.1 \\
\hline Tunisia & 0.0 & -0.2 & -0.1 & 4.1 & 0.0 & 0.9 & -0.1 & -0.1 \\
\hline Rest of Arab League & 3.1 & 6.8 & -0.2 & 1.5 & 9.1 & 1.3 & 1.3 & 13.2 \\
\hline Rest of Africa & 2.4 & 3.8 & 0.8 & 4.4 & 0.3 & 68.1 & -1.1 & 3.0 \\
\hline Central Africa & 1.2 & 1.5 & 1.2 & 0.6 & 0.1 & 2.5 & 0.2 & 0.3 \\
\hline Western Africa & -0.1 & 1.2 & -0.1 & 0.8 & 0.0 & 27.3 & -0.7 & 1.0 \\
\hline Eastern Africa & 1.2 & 2.0 & 0.4 & 0.7 & 0.6 & 12.1 & 0.5 & 1.9 \\
\hline Southern Africa & 0.0 & -0.9 & -0.7 & 2.5 & -0.3 & 26.1 & -1.0 & -0.3 \\
\hline $\begin{array}{l}\text { Emerging Industrialized } \\
\text { Economies }\end{array}$ & 30.6 & 29.3 & 33.0 & 0.8 & 4.6 & 1.6 & 36.5 & 59.6 \\
\hline Rest of the World & 146.4 & 47.0 & 50.1 & 0.6 & 5.7 & 2.1 & 51.6 & 88.4 \\
\hline
\end{tabular}

(Source) Authors' calculations based on the MIRAGE model. 


\section{Appendix 7: Main sectors of NACs' exports to destinations}

$(\%, 2010 \sim 2012)$

\begin{tabular}{|c|c|c|c|c|}
\hline & & NACs & Rest of Africa & Rest of the world \\
\hline \multirow{6}{*}{ NACs } & All food items & 17.5 & 24.7 & 4.6 \\
\hline & Agricultural raw materials & 1.0 & 2.3 & 0.5 \\
\hline & Ores and metals & 3.3 & 3.3 & 2.4 \\
\hline & Fuels & 36.0 & 12.2 & 71.4 \\
\hline & Manufactured goods & 42.2 & 47.5 & 19.5 \\
\hline & Others n.e.c. & 0.0 & 9.9 & 1.5 \\
\hline \multirow{6}{*}{ Algeria } & All food items & 2.7 & 32.1 & 0.4 \\
\hline & Agricultural raw materials & 0.0 & 0.0 & 0.0 \\
\hline & Ores and metals & 0.5 & 1.5 & 0.3 \\
\hline & Fuels & 93.6 & 57.9 & 98.6 \\
\hline & Manufactured goods & 3.2 & 8.5 & 0.8 \\
\hline & Others n.e.c. & 0.0 & 0.0 & 0.0 \\
\hline \multirow{6}{*}{ Egypt } & All food items & 24.1 & 20.6 & 12.4 \\
\hline & Agricultural raw materials & 1.5 & 4.0 & 2.1 \\
\hline & Ores and metals & 7.0 & 4.4 & 5.9 \\
\hline & Fuels & 4.2 & 3.5 & 39.7 \\
\hline & Manufactured goods & 63.2 & 44.4 & 37.2 \\
\hline & Others n.e.c. & 0.0 & 22.7 & 2.8 \\
\hline \multirow{6}{*}{ Libya } & All food items & 0.5 & 0.4 & 0.0 \\
\hline & Agricultural raw materials & 0.6 & 0.7 & 0.0 \\
\hline & Ores and metals & 1.1 & 0.2 & 0.1 \\
\hline & Fuels & 63.1 & 0.5 & 97.0 \\
\hline & Manufactured goods & 34.7 & 98.2 & 2.0 \\
\hline & Others n.e.c. & 0.0 & 0.0 & 0.8 \\
\hline
\end{tabular}




\begin{tabular}{|c|c|c|c|c|}
\hline & NACs & Rest of Africa & Rest of the world \\
\hline \multirow{6}{*}{ Morocco } & All food items & 16.7 & 32.8 & 17.8 \\
\hline & Agricultural raw materials & 4.3 & 1.1 & 1.2 \\
\hline & Ores and metals & 7.3 & 2.1 & 11.9 \\
\hline & Fuels & 6.8 & 9.6 & 4.4 \\
\hline & Manufactured goods & 64.4 & 54.3 & 63.7 \\
\hline & Others n.e.c. & 0.5 & 0.0 & 0.9 \\
\hline \multirow{6}{*}{ Sudan } & All food items & 82.3 & 5.5 & 4.7 \\
\hline & Agricultural raw materials & 14.1 & 0.2 & 1.3 \\
\hline & Ores and metals & 0.2 & 0.3 & 0.6 \\
\hline & Fuels & 0.0 & 88.6 & 74.5 \\
\hline & Manufactured goods & 3.3 & 5.2 & 1.1 \\
\hline & Others n.e.c. & 0.0 & 0.2 & 17.8 \\
\hline \multirow{6}{*}{ Tunisia } & All food items & 32.9 & 26.4 & 6.2 \\
\hline & Agricultural raw materials & 0.3 & 1.4 & 0.5 \\
\hline & Ores and metals & 1.4 & 4.7 & 1.6 \\
\hline & Fuels & 1.1 & 0.7 & 17.1 \\
\hline & Manufactured goods & 64.4 & 66.8 & 74.7 \\
\hline & Others n.e.c. & 0.0 & 0.0 & 0.0 \\
\hline
\end{tabular}

(Source) Authors' calculations based on UNCTADStat; accessed on 1 May 2015. 